\title{
Anatomic Stage IB Breast Cancer AJCC v8
}

National Cancer Institute

\section{Source}

National Cancer Institute. Anatomic Stage IB Breast Cancer AJCC v8. NCI Thesaurus.

Code C139537.

Stage IB includes: (T 0, N1 mi, M0); (T1, N1 mi, M0). T0: No evidence of primary tumor. T1:

Tumor measuring $20 \mathrm{~mm}$ or less in greatest dimension. $\mathrm{N} 1 \mathrm{mi}$ : Tumor with

micrometastases (approximately 200 cells, larger than $0.2 \mathrm{~mm}$, but none larger than 2.0

mm). M0: No clinical or radiographic evidence of distant metastases. Imaging studies are not required to assign the M0 category. (AJCC 8th ed.) 